\title{
Codified gestures i scenic learning - dwie techniki oparte na gestach i ruchu scenicznym wspomagające naukę języka angielskiego uczniów szkót podstawowych
}

\author{
Codified gestures and scenic learning - two techniques based on \\ gestures and body movement for enhancing English language learning \\ in the primary classroom
}

\author{
Monika Michalak \\ Uniwersytet im. Adama Mickiewicza w Poznaniu \\ m.michalak@amu.edu.pl | ORCID: 0000-0002-8775-8142
}

\begin{abstract}
Gestures play an important role in generating new ideas and help solve problems in a creative way. The results of the recent research indicate a lot of benefits of using codified gestures technique during a foreign language class with beginners. What is more, it has been proved that scenic learning has a positive effect on the new vocabulary retention, motivates students to learn and encourages them to express their emotions, reinforcing openness to new experiences. The following paper aims at describing the role of the two techniques in English language learning and teaching based on a research conducted among several dozens of pupils in one of the primary schools in Wielkopolska.
\end{abstract}

Keywords: drama in education, codified gestures, scenic learning, multimodal learning, neurodidactics 



\section{Wstęp}

Jak pisze Teresa Siek-Piskozub:

Zamierzonym celem nauczania jest doprowadzenie do zdobycia określonej wiedzy lub opanowania przez ucznia pewnych sprawności wyznaczonych przez program nauczania, natomiast zamierzonym celem działania uczniowskiego jest zrealizowanie celu ludycznego - doświadczenie uczucia przyjemności, rozbawienia, osiągnięcia sukcesu. Sam cel nauczania może być dla niego [tj. dla ucznia] ukryty (Siek-Piskozub, 2001, s. 19).

Powszechnie znane jest przekonanie, że gesty i ruch ciała wpływają pozytywnie na dynamikę wypowiedzi oraz wspomagają komunikację, usprawniając przywoływanie słów, których mówiący nie może sobie w danym momencie przypomnieć, czy docieranie do wyrażeń, których nie używa na co dzień. Badania dowodzą, że gesty i mowa są ze sobą ściśle powiązane. Zatem, co wydaje się oczywiste, gesty i ruch ciała mają duży potencjał dydaktyczny i mogą z powodzeniem wspomagać nauczanie oraz uczenie się języków obcych. W tej dziedzinie najczęściej kojarzone są z techniką reagowania całym ciałem (ang. total physical response, TPR), głównie w procesie wprowadzania nowego słownictwa wśród najmłodszych uczniów.

Celem niniejszego artykułu jest przybliżenie, w jaki sposób obserwowanie (i wykonywanie) konkretnych gestów oraz ruchów ciała wspomaga nabywanie i przetwarzanie języka angielskiego na poziomie zarówno pojedynczych słów, jak i całych zdań.

\section{Gesty kodowane (ang. codified gestures) - czym są i jaką rolę odgrywają podczas nauki języka obcego}

\subsection{Definicja}

Gesty kodowane są zbiorem gestów, z których każdy ma znaczenie słownikowe (najczęściej jeden gest odpowiada jednemu słowu), znane i używane przez członków określonego kręgu kulturowego lub społeczności. Grupa ta może być bardzo liczna, o zasięgu nawet światowym, lub bardzo mała, składająca się z nauczyciela i jego uczniów. Głównym celem takich gestów jest wspomaganie rozumienia przekazywanych werbalnie treści, 
a więc, aby ten cel mógł być osiągnięty, powinny one jasno i w nieskomplikowany sposób obrazować znaczenie. Gdy nauczyciel tworzy nowy gest, wykonywany przez niego symboliczny ruch ciała musi mieć semantyczny związek z treścią. Jeśli ruch ten nie kojarzy się ze słowem, gest nie zostanie zrozumiany od razu i konieczne będzie "nauczenie” się go (Poggi, 2013, s. 1481-1485)

Zatem gesty kodowane mogą mieć charakter ikoniczny ${ }^{1}$ (np. kot imitowanie dłońmi wąsów kota po obu stronach twarzy) lub bardziej umowny (np. spójnik „i” - otwarte dłonie tworzące znak +). W tym drugim przypadku źródła gestów trzeba upatrywać w językach migowych. Przy czym trzeba podkreślić, że gesty kodowane nie są tożsame z ruchami dłoni i kciuków (znakami ideograficznymi zwanymi również migami), które należą do owych języków. Gesty te nie stanowią też odrębnego języka same w sobie, chociaż mogą być częścią systemu imitującego język (np. system znaków manualnych, których zadaniem jest jak najwierniejsze odzwierciedlenie słownictwa i gramatyki języka angielskiego, ang. signing exact English, SEE) (Janzen Ulbricht, 2018).

\subsection{Gesty w (glotto)dydaktyce}

W toku przeprowadzonych badań zaobserwowano wiele korzyści płynących ze stosowania gestów jako techniki wspomagającej nauczanie języka obcego. Manuela Macedonia, Karsten Müller i Angela D. Friederici (2011) udowodnili, że gesty ikoniczne w znacznym stopniu przyczyniają się do efektywnego zapamiętywania rzeczowników konkretnych w języku obcym.

Nieskomplikowane gesty zwane „uderzeniami”2 mogą ułatwić pełniejsze zrozumienie nawet złożonych treści wyrażonych w języku obcym (Holle i in., 2012). Gesty wspierają przyswajanie języka obcego przez początkujących uczniów uczęszczających do klas wielonarodowościowych (Janzen Ulbricht, 2018). Ponadto wspomaganie nauczania języka angielskiego techniką gestów kodowanych stymuluje naturalną ciekawość

1 Gesty ikoniczne odzwierciedlają związek pomiędzy formą, jaką przyjmuje gest (np. pozycja ciała, ustawienie dłoni, sposób poruszania się), a osobą, konkretnym przedmiotem, czynnością czy sytuacją, którą ilustruje (Behne, Carpenter, 2014, s. 2049).

2 Ang. beat gestures/beats - krótkie i rytmiczne ruchy dłoni dopasowane do tempa mowy, pełniące funkcję podkreślania lub komentowania przekazywanych werbalnie treści (Holle $\mathrm{i}$ in., 2012, s. 1). 
uczniów oraz rozwija ich zainteresowanie tym językiem, a także pozwala nabywać umiejętności językowe na różne sposoby (multimodalnie) (Janzen Ulbricht, Michalak, 2019).

\section{Technika wspomagająca nauczanie języka obcego oparta na ruchu scenicznym (ang. scenic learning)}

\subsection{Charakterystyka scenic learning ( $\mathrm{sL}$ )}

Scenic learning jest techniką wywodzącą się z dramy ${ }^{3}$, która łączy w sobie chóralne (grupowe) powtarzanie fragmentów tekstu (zwrotów lub pełnych zdań) przy jednoczesnym imitowaniu ich znaczeń za pomocą ruchów ciała, gestów i mimiki twarzy w celu przyswojenia nowego słownictwa w języku obcym. Nauka może odbywać się m.in. poprzez odgrywanie uprzednio przygotowanych ról (scenki rodzajowe, skecze, przedstawienia) oraz improwizację (Janzen Ulbricht, 2018).

\subsection{Znaczenie i rola SL na lekcji języka obcego}

Badanie przeprowadzone przez Markusa Kiefera, Eun-Jin Sim, Sarah Liebich, Olafa Hauka i Jamesa Tanakę (2007) dowiodło, że nowe słowa w języku obcym są przyswajane łatwiej, jeśli ów proces wesprze się przez powiązane ze znaczeniem tych słów ruchy ciała wykonywane samodzielnie przez uczącego się.

Technika SL kładzie nacisk przede wszystkim na działania samych uczniów (i nauczycieli). Kluczowy jest tu proces uczenia się i nabywania nowych umiejętności poprzez osobiste fizyczne i emocjonalne zaangażowanie uczących się. Efekt końcowy w postaci przygotowanego występu przed publicznością nie należy do warunków koniecznych. Kluczowym założeniem SL na lekcji języka obcego jest natomiast zachęcenie uczniów do wcielania się w różne role i włączanie ich w rozmaite sytuacje, które mają za zadanie naturalnie absorbować ich uwagę i stanowić dla nich źródło radości i fascynacji (Sambanis i in., 2013).

3 Metoda inicjująca i wspomagająca uczenie się, mająca swoje źródło w zabiegach teatralnych, promująca holistyczne podejście do ucznia (zob. m.in. Machulska, Pruszkowska, Tatarowicz, 1997). 
Poza aspektami pragmatycznymi, do jakich zaliczyć trzeba nabywanie umiejętności wyrażania siebie i komunikowania się w języku obcym, stosowanie techniki scenic learning na lekcji może wpływać pozytywnie na rozwój osobisty uczniów w zakresie kompetencji społecznych oraz (inter)kulturowych, a także rozwijać u nich wrażliwość na piękno i sztukę (tamże, s. 74).

\section{Neuronaukowe podstawy omawianych technik}

Wspomaganie nauczania języka obcego technikami opartymi na ruchu ciała jest uzasadnione kilkoma czynnikami neuronaukowymi.

Gesty i ruch ciała w sposób naturalny stanowią niewerbalną składową procesu komunikowania się z otaczającym światem. Badania dowodzą, że część mózgu odpowiedzialna za powstawanie mowy - ośrodek Broki aktywizuje się znacząco podczas procesów motorycznych. Przykładem może być eksperyment, w którym obserwacja cienia dłoni imitującej zwierzęta zintensyfikowała działanie tego ośrodka, dowodząc jego udziału w procesie interpretowania gestów i czynności wykonywanych przez inne osoby (Fadiga i in., 2006).

Na podstawie badań przeprowadzonych pod kierownictwem Jerzego Konorskiego poświadczono, że aktywacja neuronów wpływa bezpośrednio na tworzenie obwodów uczących się. Ponadto dowiedziono, „że siła połączenia pomiędzy neuronami wzrasta pod wpływem aktywacji sąsiednich neuronów różnymi bodźcami [podkreśl. M. M.]" (Domżał, 2013, s. 158), dzięki czemu przekazywanie informacji jest efektywniejsze.

Wśród sześciu typów neuroplastyczności ${ }^{4}$ (kategoryzacja ze względu na czynnik aktywizujący procesy plastyczności w mózgu) wymienia się m.in. plastyczność wywołaną wzmożonym doświadczeniem. Należy ją rozumieć jako „zdolność zdrowego lub uszkodzonego mózgu do przekształcania się pod wpływem wzmożonego doświadczenia czuciowego lub ruchowego, w wyniku których określone szlaki neuronalne są wzmacniane przez ciągłe

4 Neuroplastyczność (ang. neural plasticity) - zdolność mózgu polegająca na ustawicznym rozwoju, reagowaniu i przystosowywaniu się do zmieniających się warunków (np. zapamiętywanie, uczenie się nowych umiejętności) (Panasiuk, 2016, s. 166). 
powtórzenia" (Panasiuk, 2016, s. 177). Zatem można założyć, że wzbogacenie procesu glottodydaktycznego o techniki oparte na ruchu ciała zwiększy efektywność uczenia się języka obcego poprzez umożliwienie uczniom nabywania go różnymi kanałami zmysłowymi - nie tylko za pośrednictwem wzroku lub/i słuchu (uczenie się/nauczanie polisensoryczne).

Techniki oparte na ruchu całego ciała i gestach, umiejętnie zastosowane podczas takiej lekcji, niwelują destrukcyjny stres i wyzwalają pozytywne emocje, wprawiając uczniów w nastrój beztroski i odprężenia, charakterystyczny dla zabawy (Sambanis i in., 2013, s. 77). Badania dowodzą, że pod wpływem pozytywnych emocji (np. radości, zadowolenia, zainteresowania, miłości) mózg intensyfikuje procesy uwagi, zapamiętywania i angażowania się w wykonywane zadania, dzięki czemu rozwija się trwały i szeroki repertuar kompetencji fizycznych, intelektualnych oraz społecznych (Fredrickson, 1998, s. 307-311).

Jak zauważają Sambanis i in. (2013, s. 77), towarzyszące przekazowi werbalnemu gesty i ruch ciała wspierają mózg w filtrowaniu informacji i zapamiętywaniu nowych jednostek leksykalnych, nadając im priorytetowe znaczenie. Proces ten ma charakter indywidualny i uwarunkowany jest sposobem postrzegania świata oraz doświadczeniem uczącego się. Rolę filtra może spełniać chociażby aspekt nowości, poziom jasności przekazu czy wartość emocjonalna, a co warto podkreślić, omawiane w niniejszym artykule techniki stwarzają okazję do aktywowania każdego z nich.

\section{Zastosowanie techniki gestów kodowanych oraz scenic learning w nauczaniu angielskich przyimków miejsca i ruchu wśród uczniów szkoły podstawowej}

Przedstawione w tej części pracy sposoby zastosowania omawianych technik na lekcji języka obcego, spostrzeżenia autorki oraz opinie uczniów pochodzą $\mathrm{z}$ opisu badania ${ }^{5}$ przeprowadzonego w celu porównania

5 Badanie zostało przeprowadzone w jednej z wielkopolskich szkół podstawowych (teren wiejski) w roku szkolnym 2017/2018 i było częścią większego niemiecko-polskiego projektu badawczego. Wstępne wyniki zostały zaprezentowane na konferencji „Challenges of Foreign Language Teaching VIII: Through the Lens of Experience” w Uściu nad Łabą, w marcu 2018. 
skuteczności obu technik w kontekście nauczania wybranych angielskich przyimków określających ruch i położenie. Pomimo że badanie owo miało charakter komparatystyczny - obejmowało uczniów i polskich, i niemieckich szkół - rozważania tu prezentowane będą dotyczyły tylko grupy polskiej. Podjęcie takiej decyzji umotywowane jest faktem, że autorka była odpowiedzialna za wdrożenie procedury badawczej tylko w tej grupie oraz pełniła rolę jednego z dwóch nauczycieli pracujących z uczniami na podstawie obu technik, co wiązało się z koniecznością przejścia odpowiedniego przeszkolenia z zakresu gestów kodowanych oraz wymuszało samodzielne opracowanie repertuaru gestów i ruchów ciała (na potrzeby scenic learning).

Badanie miało formę trwającego pięć dni projektu teatralnego, którego celem było opanowanie przez 50 uczniów szkoły podstawowej (dwa oddziały klasy piątej i dwa szóstej) najpierw tekstu nieskomplikowanej sztuki, a docelowo - jak największej liczby angielskich przyimków występujących w tym tekście. Uczniowie zostali losowo podzieleni na cztery grupy, przy czym dwie z nich uczyły się tekstu tylko przy zastosowaniu gestów kodowanych, a dwie pozostałe - techniką scenic learning. W celu wiarygodnego potwierdzenia zakładanego przyrostu wiedzy poziom znajomości przyimków określono w tygodniu poprzedzającym projekt teatralny za pomocą narzędzia obejmującego trzy poziomy trudności. Testowanie stopnia znajomości angielskich przyimków powtórzono w tygodniu bezpośrednio po zakończeniu projektu oraz sześć tygodni później (ocena efektów długotrwałych). W celu uwiarygodnienia wyników opracowano kilka wariantów testu.

\subsection{Materiał dydaktyczny}

Wszystkie działania uczniów i nauczycieli podejmowane podczas tygodnia teatralnego skupiały się wokół prostego scenariusza przedstawienia, który został leksykalnie i gramatycznie dostosowany do poziomu znajomości języka angielskiego uczniów biorących udział w badaniu. Tekst był adaptacją znanej bajki dla dzieci zatytułowanej Bears in the Night autorstwa Stana i Jana Berenstainów, w której siedem misiów postanawia opuścić łóżko tuż przed zaśnięciem i odnaleźć źródło dochodzących z zewnątrz odgłosów. Motyw wędrówki i pokonywania różnych fizycznych przeszkód po drodze sprzyjał wdrażaniu angielskich przyimków 
miejsca i ruchu w kontekście (np. „Let's go under the bridge! [Przejdźmy pod mostem!]").

\subsection{Nauka przy pomocy gestów kodowanych}

Podczas nauki tekstu uczniowie siedzieli w półkolu zwróceni twarzą do nauczyciela, który stał naprzeciwko nich. Przychodził do sali ze stojakiem do nut i na nim umieszczał tekst. W trakcie początkowych sesji bardzo wolno czytał poszczególne fragmenty tekstu i gestykulował przy tym. Kolejne sesje miały podobny przebieg, tyle że tempo mówienia zwiększało się. Założono, iż uczniowie wraz ze słowami występującymi w tekście będą zapamiętywali towarzyszące im gesty. Zadaniem słuchaczy było włączenie się do wygłaszania tekstu w chwili, gdy rozpoznali gest. Chociaż ich aktywność polegała na mówieniu (nie na gestykulowaniu), zaobserwowano, że większość z nich wykonywała również właściwe gesty.

Nauka tekstu odbywała się w 12 sesjach po 15 minut (trzy sesje w ciągu dnia dla każdej z grup), podczas których uczniowie nie mieli dostępu do wersji pisanej. Nauczyciel gestykulował na poziomie morfemu, w związku z czym jedno słowo mogło składać się z dwóch gestów (np. „bears [niedźwiedzie]" - jeden gest oznaczał niedźwiedzia, drugi wskazywał na liczbę mnogą). Każdemu słowu (morfemowi) w tekście odpowiadał gest, a więc w przypadku nauki tekstu techniką gestów kodowanych całość była wyrażona gestami.

\subsection{Nauka techniką scenic learning}

Podczas pierwszej z 12 sesji trwających kwadrans uczniowie, siedzący w kręgu, zostali poproszeni o zrelaksowanie się, przybranie wygodnej pozycji i wysłuchanie całego tekstu, czytanego w wolnym tempie przez nauczyciela. Następnie sytuacja powtórzyła się, przy czym tym razem zadaniem uczniów było zidentyfikować jak najwięcej znanych im słów. Później uczestnicy zajęć otrzymali kopie scenariusza i z pomocą nauczyciela kontynuowali „oswajanie się” z jego treścią - śledzili tekst długopisem, gdy nauczyciel czytał; głośno kończyli rozpoczęte przezeń zdania; zgłębiali tekst w grupach itp. Takie działania uczniów i nauczyciela miały miejsce w trakcie sześciu sesji, a ich celem było pełne zrozumienie treści oraz płynne czytanie tekstu. 
Podczas sesji 7-12 uczniowie zostali pozbawieni tekstów pisanych, a nauczyciel kontynuował pracę, opierając się na uprzednio przygotowanym zestawie ruchów ciała i gestów. W tej fazie uczestnicy zgromadzeni byli na środku sali lekcyjnej i w zależności od fragmentu powtarzanego wraz z nauczycielem w danym momencie przybierali określone pozy, wykonywali ruchy, wskazywali lub gestykulowali (np. „And down the tree! [I w dół po drzewie!]" - stojący uczniowie kucają stopniowo do pozycji siedzącej, wypowiadając przy tym wspomniane zdanie i charakterystycznie przedłużając wyrazy, co ma imitować czynność zjeżdżania). Warto zaznaczyć, że w przypadku stosowania techniki scenic learning gesty i ruchy ciała odpowiadały całym zdaniom i zostały przyporządkowane około $80 \%$ tekstu.

\subsection{Przedstawienie}

Jak wspomniano w części teoretycznej niniejszego artykułu, występowanie przed publicznością nie jest konieczne podczas wykorzystywania technik wywodzących się z dramy w procesie (glotto)dydaktycznym. Niemniej jednak grupa uczniów biorących udział w badaniu z entuzjazmem podeszła do pomysłu zaprezentowania efektów swojej pracy społeczności szkolnej.

W trakcie pierwszych sesji uczenia się tekstu wyjaśniono uczniom, że każdy z nich powinien opanować całość, niezależnie od tego, jaką rolę będzie odgrywał na scenie. Kwestie „mówione” (misie, sowa, narratorzy) rozdysponowano po ostatniej sesji, przy czym wcześniej grupy zostały połączone i ponownie podzielone na dwa zespoły artystyczne (bez uwzględniania techniki, jaką były uczone tekstu). Uczniowie, którzy nie otrzymali roli, mieli za zadanie stanowić żywy (ruchomy i mówiący) element scenografii (np. dzieci tworzące most powtarzały razem wyrażenie "under the bridge" w trakcie przechodzenia misiów pod mostem).

W dniu występu (ostatni dzień projektu teatralnego) wszyscy uczestnicy badania wspólnie przygotowywali scenografię i kostiumy. Przed premierą odbyła się próba generalna. Sam spektakl okazał się nie tylko nowym doświadczeniem emocjonalnym dla uczniów, ale również prawdziwym sprawdzianem $\mathrm{z}$ umiejętności współpracy w zespole oraz panowania nad tremą. Ponadto wpłynął na podniesienie samooceny tych, którzy z natury są raczej nieśmiali i nie wierzą we własne możliwości. 
Oto kilka wypowiedzi zanotowanych przez nauczyciela w ostatnim dniu projektu (Michalak, 2017) ${ }^{6}$ :

Najtrudniej było zapamiętać, kiedy była moja kolej. Fajnie, że wszystkie misie były ustawione w dobrej kolejności [tj. zgodnie z kolejnością kwestii w scenariuszu - M. M.] i miały numerki na piżamach. Pomagało też podawanie sobie mikrofonu".

Nie przeszkadza mi, że trzymam te gałęzie. Niby tylko siedzimy, ale misie potrzebują nas, żeby móc przejść wokół jeziora ${ }^{8}$.

Cieszę się, że mogliśmy wystąpić razem i nie musiałem nic mówić sam na środku sali. Całe przedstawienie było taką grą, którą oglądali inni. Nawet nie przejmowałem się publicznością?.

\section{Rezultaty i podsumowanie}

Obie techniki w znacznym stopniu przyczyniły się do podniesienia poziomu znajomości angielskich przyimków miejsca i ruchu. Wstępne opracowanie danych empirycznych wykazało, że uczniowie przyswajający tekst techniką gestów kodowanych na poziomie morfologii opanowali wykorzystane w nim przyimki w nieco większym stopniu niż uczniowie, którzy zostali poddani działaniu gestów i ruchów ciała na poziomie zdania. Ostatni pomiar, wykonany sześć tygodni po zakończeniu projektu teatralnego, poświadczył jednak, że obie metody były skuteczne niemal w równym stopniu. Ze względu na ograniczenia objętościowe oraz inne ukierunkowanie tego artykułu wyniki statystyczne nie zostaną tutaj szczegółowiej omówione, ale będą dostępne w pracy Janzen Ulbricht (2020, w druku).

Techniki oparte na gestach i ruchu ciała niewątpliwie wniosły wiele radości i nowych doświadczeń do sali lekcyjnej, aktywizując nawet tych uczniów, którzy na wstępie manifestowali brak zainteresowania nauką

6 Nauczyciele biorący udział w badaniu prowadzili dzienniki, w których zapisywali swoje spostrzeżenia oraz wypowiedzi uczniów mające związek z przebiegiem samego badania i występem końcowym. W celu zachowania anonimowości uczestników ich imiona zostały zmienione.

7 Ania, lat 11, w odpowiedzi na pytanie nauczyciela zadane po przedstawieniu: „Co było dla ciebie najtrudniejsze podczas występu?".

8 Tomek, lat 10, w odpowiedzi na zadane po próbie generalnej pytanie: „Czy nie wolałbyś odgrywać jednej z głównych ról, zamiast tworzyć jezioro wraz z innymi kolegami?”.

9 Eryk, lat 12, w odpowiedzi na zadane po spektaklu pytanie: „Co najbardziej podobało ci się w tym przedstawieniu?". 
języka obcego i wątpili w powodzenie całego projektu. Intencją autorki było zaprezentowanie przykładowego wykorzystania tych technik na lekcji języka obcego oraz wskazanie ich potencjału dydaktycznego, szczególnie w przypadku grup uczniów z drugiego etapu edukacyjnego (klasy 4-6), znających język angielski na poziomie podstawowym.

\section{Literatura}

Behne, T., Carpenter, M. (2014). Young Children Create Iconic Gestures to Inform Others. Developmental Psychology, 50(8), 2049-2060.

Domżał, T. M. (2013). Pamięć w neurologii: zaburzenia, diagnostyka i leczenie. Forum Medycyny Rodzinnej, 7(4), 155-164.

Fadiga, L., Craighero, L., Destro, M. F., Finos, L., Cotillon-Williams, N., Smith, A. T., Castello, U. (2006). Language in shadow. Social Neuroscience, 1(2), 77-89.

Fredrickson, B. L. (1998). What Good Are Positive Emotions? Review of General Psychology, 2(3), 300-319.

Holle, H., Obermeier, C., Schmidt-Kassow, M., Friederici, A. D., Ward, J., Gunter, T. C. (2012). Gesture Facilitates the Syntactic Analysis of Speech. Frontiers in Psychology, 74(3), 1-12. Online: <http://www.ncbi.nlm.nih. gov/pmc/articles/PMC3307377>. Data dostępu: 17 października 2020.

Janzen Ulbricht, N. (2018). An experiment on gesture and fluency in two German schools. ELT Journal, 72(3), 309-318.

Janzen Ulbricht, N. (2020). The Embodied Teaching of Spatial Terms: Gestures Mapped to Morphemes Improve Learning. Frontiers in Education, 5(7), 1-13. Online: <https://refubium.fu-berlin.de/bitstream/ handle/fub188/27818/feduc-05-00109.pdf?sequence=2\&isAllowed $=y>$. Data dostępu: 7 grudnia 2020.

Janzen Ulbricht, N., Michalak, M. (2019). Codified gestures, curiosity and group cohesion in the foreign language classroom. W: Ch. Haase, N. Orlova (red.), English Language Teaching through the Lens of Experience (s. 207-221). Newcastle upon Tyne: Cambridge Scholars Publishing.

Kiefer, M., Sim, E.-J., Liebich, S., Hauk, O., Tanaka, J. (2007). Experience-dependent Plasticity of Conceptual Representations in Human Sensory-Motor Areas. Journal of Cognitive Neuroscience, 19(3), 525-542. 
Macedonia, M., Müller, K., Friederici, A. D. (2011). The Impact of Iconic Gestures on Foreign Language Word Learning and Its Neural Substrate. Human Brain Mapping, 32(6), 982-998. Online: <http://onlinelibrary. wiley.com/doi/epdf/10.1002/hbm.21084>. Data dostępu: 16 października 2020.

Machulska, H., Pruszkowska, H., Tatarowicz, J. (1997). Drama w szkole podstawowej. Warszawa: WSiP.

Michalak, M. (2017). Nieopublikowane notatki z dziennika prowadzonego podczas trwania projektu teatralnego Bears in the Night.

Panasiuk, J. (2016). Uczenie się a mechanizmy neuroplastyczności. Annales Universitatis Mariae Curie-Sklodowska, sectio N - Educatio Nova, 1(1), 163-179. Online: <http://yadda.icm.edu.pl/yadda/element/bwmeta1. element.ojs-doi-10_17951_en_2016_1_163/c/4779-3539.pdf>. Data dostępu: 17 października 2020.

Poggi, I. (2013). Semantics and pragmatics of symbolic gestures. W: C. Müller, A. Cienki, E. Fricke, S. Ladewig, D. McNeill, S. Tessendorf (red.), Body - Language - Communication: An International Handbook on Multimodality in Human Interaction. Berlin-Boston: De Gruyter Mouton.

Sambanis, M., Baran, D., Beltrop, K., Grabert, L., Knorr-Dadfar, J., Marz, J., Schneider, A., Splitt, F., Wonschik, K. (2013). DRAMA TO GO! Hints and hands-on activities for the classroom. Scenario, 7(1), 73-92. Online: <http://publish.ucc.ie/journals/scenario/2013/01/Sambanis/05/en>. Data dostępu: 17 października 2020.

Siek-Piskozub, T. (2001). Uczyć się bawiąc. Strategia ludyczna na lekcji języka obcego. Warszawa: Wydawnictwo Naukowe PWN.

mgr Monika Michalak - nauczycielka języka angielskiego, doktorantka w Instytucie Lingwistyki Stosowanej Uniwersytetu im. Adama Mickiewicza w Poznaniu

\section{Codified gestures i scenic learning - dwie techniki oparte na gestach i ruchu scenicznym wspomagające naukę języka angielskiego u uczniów szkót podstawowych}

Abstrakt: Gesty petnią istotną rolę w generowaniu nowych pomysłów i po-
magają rozwiązywać problemy w sposób kreatywny. Wyniki najnowszych
badań wskazują na wiele korzyści płynących ze stosowania tzw. gestów 
kodowanych na lekcjach języka obcego z początkującymi uczniami. Ponadto wdrożenie elementów ruchu scenicznego ma pozytywny wpływ na zapamiętywanie przez uczniów nowego słownictwa, motywuje ich do nauki, zachęca do wyrażania emocji i otwiera na nowe doświadczenia. Celem niniejszego artykułu jest ukazanie znaczenia i roli tych dwóch technik w nauczaniu języka angielskiego na przykładzie badania przeprowadzonego wśród kilkudziesięciu uczniów jednej z wielkopolskich szkół podstawowych.

Stowa kluczowe: drama w edukacji, gesty kodowane, technika uczenia się oparta na ruchu scenicznym, neuro(glotto)dydaktyka, polisensoryczne uczenie się 